\title{
ANALISIS HEAT TRANSFER PADA BETON MASSA MENGGUNAKAN OPC TIPE I DALAM HUBUNGAN DENGAN CARA CURING
}

\author{
Billy Setiawan ${ }^{1}$ dan F.X. Supartono ${ }^{2}$ \\ ${ }^{1}$ Program Studi Sarjana Teknik Sipil, Universitas Tarumanagara, Jl. Letjen S. Parman No.1 Jakarta \\ Email: setiawanbilly96@yahoo.com \\ ${ }^{2}$ Program Studi Sarjana Teknik Sipil, Universitas Tarumanagara, Jl. Letjen S. Parman No.1 Jakarta \\ Email: fxsupartono@gmail.com
}

\begin{abstract}
ABSTRAK
Skripsi ini membahas tentang heat transfer dan tegangan yang terjadi pada pilecap bermassa besar di Jembatan Pulau Balang, Kalimantan Timur. Pada pekerjaan konstruksi beton massa, sering kali dihadapkan dengan masalah-masalah tertentu yang biasanya diakibatkan oleh kelalaian dalam pembuatan beton massa tersebut. Salah satunya adalah timbulnya crack pada permukaan beton massa. Crack ini biasa diakibatkan oleh proses curing yang kurang tepat, ataupun pemakaian semen yang berlebih. Dimensinya yang besar juga dapat mengakibatkan bagian dalam beton sulit untuk melepaskan panas. Adanya perbedaan temperatur yang besar antara permukaan dan inti beton dapat menimbulkan tegangan yang mana dikhawatirkan akan melampaui kuat tarik beton, sehingga menimbulkan retak pada permukaan beton. Dalam penelitian ini, metode curing dan initial temperature akan menjadi variabel bebas, yang mana akan mempengaruhi temperatur yang terjadi. Menurut literatur, temperatur maksimum yang diijinkan adalah $70^{\circ} \mathrm{C}$, sedangkan perbedaan temperatur harus lebih kecil dari $20^{\circ} \mathrm{C}$. Dalam penelitian ini, dibuat opsi curing dengan cara isolasi dan temperatur awal yang rendah (perbedaan temperatur yang terjadi $11,7^{\circ} \mathrm{C}$ ). Sedangkan untuk opsi tanpa isolasi sudah tidak memenuhi persyaratan (perbedaan temperatur yang terjadi $33^{\circ} \mathrm{C}$ ) dan terjadi thermal crack pada permukaan beton. Pemasangan lapisan isolator dengan metode buka tutup dapat menjadi cara alternatif, namun berisiko terjadi thermal shock dan harus dilakukan trial and error untuk menghindari hal tersebut.
\end{abstract}

Kata kunci: beton massa, isolator, temperatur maksimum, perbedaan temperatur, tegangan.

\section{PENDAHULUAN}

Di zaman sekarang ini, kebutuhan konstruksi di Indonesia terus-menerus berkembang, terutama pada gedunggedung bertingkat tinggi. Tentunya dalam konstruksi gedung tingkat tinggi ini memerlukan pondasi dan pilecap yang sangat besar agar mampu menahan gaya-gaya yang ditimbulkan oleh struktur atas tersebut. Pada umumnya, pondasi dan pilecap merupakan salah satu contoh dari beton bermassa besar. Pada pekerjaan konstruksi beton massa, sering kali dihadapkan dengan masalah-masalah tertentu yang biasanya diakibatkan oleh kelalaian dalam pembuatan beton massa tersebut. Salah satunya adalah timbulnya crack pada permukaan beton massa.

Crack ini biasa diakibatkan oleh proses curing yang kurang tepat, ataupun pemakaian semen yang berlebih. Pada umumnya, panas pada beton akan mengakibatkan beton mengembang, sedangkan jika beton sudah mengeras, maka beton tersebut akan menyusut. Pada beton massa, biasanya bagian luar lebih cepat mengeras daripada bagian dalam. Hal seperti cenderung menimbulkan tegangan internal beton yang mana jika melampaui kuat tarik beton, akan menimbulkan crack pada permukaan beton tersebut.

Oleh karena itu, berdasarkan latar belakang di atas, peneliti bermaksud untuk mencari perubahan/penyebaran temperatur serta tegangan yang timbul selama proses pengerasan.

\section{Identifikasi masalah}

Jurnal ini membahas tentang penyebaran temperatur dengan semen portland tipe I dan perbedaan tegangan yang timbul.

\section{Batasan masalah}

Adapun batasan-batasan dalam penelitian ini, antara lain:

a. Beton yang akan dimodelkan adalah beton massa (pilecap). 
b. Semen yang digunakan adalah semen portland tipe I.

c. Metode curing yang digunakan yaitu:

- Metode penyiraman dengan air.

- Metode isolasi dengan lapisan styrofoam, pasir dan plastik.

- Metode isolasi sistem buka tutup.

d. Menggunakan air es (suhu awal $18^{\circ} \mathrm{C}$ ) dan air biasa (suhu awal $30^{\circ} \mathrm{C}$ ) sebagai campuran adukan beton.

e. Perhitungan analisa menggunakan bantuan software midas Civil 2018.

f. Hasil yang diperoleh berupa penyebaran temperatur dan tegangan selama proses pengerasan beton.

\section{Rumusan masalah}

Permasalahan yang akan dibahas dalam penelitian ini adalah:

a. Apa pengaruh panas hidrasi semen OPC tipe I pada beton massa?

b. Bagaimana penyebaran temperatur dalam beton selama proses pengerasan berlangsung?

c. Berapakah tegangan yang timbul selama proses pengerasan berlangsung?

\section{Tujuan penelitian}

a. Mengetahui pengaruh panas hidrasi semen OPC tipe I pada beton massa.

b. Mengetahui penyebaran/perubahan temperatur dalam beton selama proses pengerasan berlangsung.

c. Mengamati tegangan yang timbul selama proses pengerasan berlangsung.

\section{TINJAUAN PUSTAKA}

\section{Beton massa}

Beton massa merupakan beton yang memiliki dimensi yang sedemikian besar, sehingga dibutuhkan tindakantindakan khusus dalam proses pengecorannya. Tindakan ini berupa pengendalian suhu thermal akibat dari hidrasi semen serta perubahan volume beton untuk mengurangi keretakan atau cracking. Beton dengan ketebalan minimal 1,3 meter dapat dikatagorikan sebagai mass concrete atau beton massa.

Beton massa ini biasa diaplikasikan dalam bentuk pilecap (terutama raft foundation), pillar besar, thick slabs, dan beton dengan dimensi tebal lainnya. Seperti halnya beton biasa, hal-hal yang perlu diperhatikan pada beton massa ini adalah perubahan temperatur, kuat tekan, dan durability. Namun, yang patut diperhatikan dalam beton massa ini adalah perubahan temperatur, karena dimensinya yang besar dapat mengakibatkan bagian dalam beton sulit untuk melepaskan panas. Adanya perbedaan temperatur pada bagian beton ini dapat menimbulkan tegangan internal beton yang mana dikhawatirkan akan melampaui kuat tarik beton, sehingga menimbulkan retak pada permukaan beton.

\section{Semen}

Semen merupakan salah satu aspek penting dalam pembuatan beton dan merupakan campuran dari berbagai senyawa kimia yang bersifat hidrolis. Hidrolis artinya apabila suatu bahan dicampur dengan air dalam jumlah tertentu akan mengikat bahan-bahan lain menjadi satu kesatuan massa yang dapat memadat dan mengeras serta tidak larut. Secara umum, semen dapat didefinisikan sebagai bahan perekat yang dapat merekatkan bagian-bagian benda, dua atau lebih benda sehingga menjadi bentuk yang kuat, kompak dan keras. Salah satu jenis semen yang umum dipakai adalah semen portland dengan berbagai tipe dan karakteristik seperti yang dijelaskan dalam Tabel 1

.Tabel 1. Jenis semen Portland dengan sifatnya

\begin{tabular}{ccccccc}
\hline \multirow{2}{*}{ Tipe semen } & Sifat pemakaian & \multicolumn{3}{c}{ Kadar senyawa (\%) } & \multirow{2}{*}{$\begin{array}{c}\text { Panas hidrasi } \\
(\mathrm{J} / \mathrm{kg})\end{array}$} \\
\cline { 3 - 5 } & Umum & $\mathrm{C}_{3} \mathrm{~S}$ & $\mathrm{C}_{2} \mathrm{~S}$ & $\mathrm{C}_{3} \mathrm{~A}$ & $\mathrm{C}_{4} \mathrm{AF}$ & 330 \\
\hline I & Moderate & 42 & 33 & 5 & 13 & 250 \\
\hline III & $\begin{array}{c}\text { Kekuatan awal } \\
\text { tinggi }\end{array}$ & 60 & 13 & 9 & 8 & 500 \\
\hline IV & $\begin{array}{c}\text { Panas hidrasi } \\
\text { rendah }\end{array}$ & 25 & 50 & 5 & 12 & 210 \\
\hline $\mathrm{V}$ & Tahan sulfat & 40 & 40 & 9 & 9 & 250 \\
\hline
\end{tabular}




\section{Curing}

Curing merupakan suatu langkah yang perlu dilakukan dalam proses pembuatan beton dimana beton diberi kesempatan untuk memaksimalkan atau mengembangkan kekuatannya sesempurna mungkin. Proses curing biasanya dilakukan setelah beton mencapai fase hardening atau proses pengerasan. Proses curing sangat berperan penting dalam pembentukan kekuatan beton. Pasalnya, selama beton masih dalam proses pengerasan, beton tersebut akan terus menghasilkan panas yang disebabkan oleh proses hidrasi antara campuran semen dengan air. Jika tidak dilakukan proses curing, dikhawatirkan akan terjadi thermal cracking, yang artinya retak yang disebabkan oleh perbedaan temperatur pada sisi luar dan dalam beton. Adanya perbedaan temperatur ini dapat mengakibatkan terjadinya tegangan pada beton, sehingga menimbulkan retak.

Salah satu metode curing yang paling umum adalah dengan disiram air secara berkala. Selama beton masih dalam proses pengerasan, beton akan terus kehilangan air akibat penguapan karena panas. Kehilangan air dalam beton secara terus-menerus dapat mengganggu proses hidrasi, sehingga memicu timbulnya keretakan pada beton. Curing dengan penyiraman air terhadap beton secara berkala bertujuan untuk menggantikan air yang hilang selama proses hidrasi berlangsung. Penyiraman dilakukan ke semua sisi beton yang direndam, sehingga pengeringan tidak akan mungkin terjadi dan beton tidak akan kehilangan air yang dibutuhkannya untuk proses pengerasan.

Metode lain dalam proses curing yaitu dengan metode isolasi. Pada curing ini, beton ditutup/diselimuti dengan material yang bersifat isolator, yang artinya material tersebut sulit untuk menghantarkan panas. Material yang bersifat isolator ini umumnya dapat berupa styrofoam, pasir, plastik, dan sebagainya. Metode ini bertujuan untuk mencegah panas dalam beton agar tidak keluar (penguapan), sehingga air yang dibutuhkan beton tidak hilang dengan mudah dan proses hidrasi tetap terus berjalan. Metode ini lebih mudah untuk dilakukan, namun terdapat resiko, yaitu tidak dapat menggantikan air yang hilang selama proses pengecoran maupun pengerasan karena pasti akan ada kandungan air yang hilang dalam jumlah yang kecil.

Selain itu, jika material isolator ini dilepas sebelum proses pengerasan selesai, maka dapat menyebabkan terjadinya thermal shock, yaitu tegangan yang terjadi akibat perubahan suhu yang mendadak antara permukaan beton dengan lingkungan luar. Hal ini terjadi karena tingginya temperatur permukaan beton akibat lapisan isolator.

\section{Thermal stress dan thermal crack}

Thermal stress (tegangan termal) dan thermal cracking (retak termal) merupakan 2 keadaan yang sering muncul dalam proses pembuatan beton massa. Dalam pembuatan mass concrete, temperatur selalu menjadi permasalahan utama karena beton memiliki sifat poor thermal conductivity, yang artinya beton, terutama beton massa membutuhkan waktu yang relatif lama atau sulit untuk melepaskan panas yang terkandung dalam beton tersebut.

Dari keadaan tersebut, timbullah tegangan termal, yaitu tegangan yang disebabkan oleh adanya perbedaan suhu. Perpindahan panas antara permukaan beton dengan lingkungan sekitar menyebabkan bagian permukaan beton lebih cepat melepas panas dibandingkan dengan bagian dalam beton.

Jika tegangan termal dibiarkan terus-menerus, akibatnya akan terjadi thermal cracking, yaitu retak pada permukaan beton yang disebabkan oleh tegangan yang terjadi pada beton. Menurut literatur, perbedaan suhu antara permukaan beton dengan inti beton tidak boleh melebihi $20^{\circ} \mathrm{C}$ dan suhu maksimum yang boleh diterima beton adalah $70^{\circ} \mathrm{C}$. Retak termal dapat dihindari dengan cara mengendalikan suhu pada beton, diantaranya adalah dengan curing, ataupun memakai semen dengan panas hidrasi rendah (portland cement tipe IV).

Tegangan termal yang terjadi diilustrasikan pada Gambar 1.

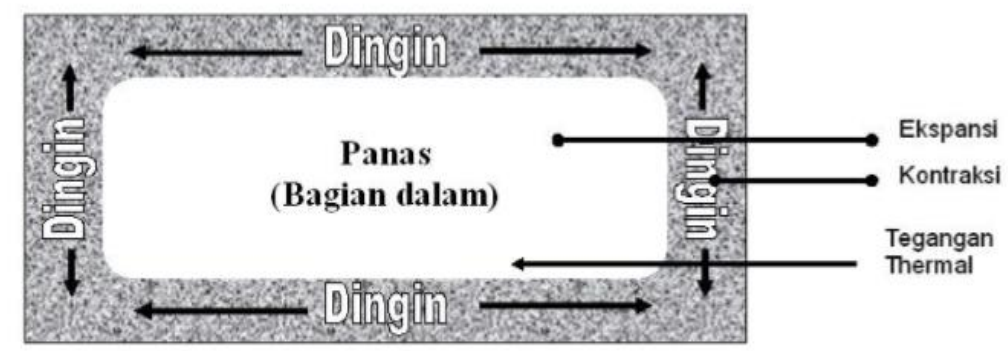

Gambar 1. Ilustrasi tegangan termal pada beton. 


\section{METODE PENELITIAN}

Dalam penelitian ini, dipakai program Midas Civil 2018 untuk menghitung penyebaran temperatur dan tegangan yang timbul dengan berbagai variabel bebas, yaitu opsi curing dan temperatur awal. Adapun tahapan dalam menganalisis heat transfer pada beton massa akan dijelaskan pada Gambar 2 berikut ini.

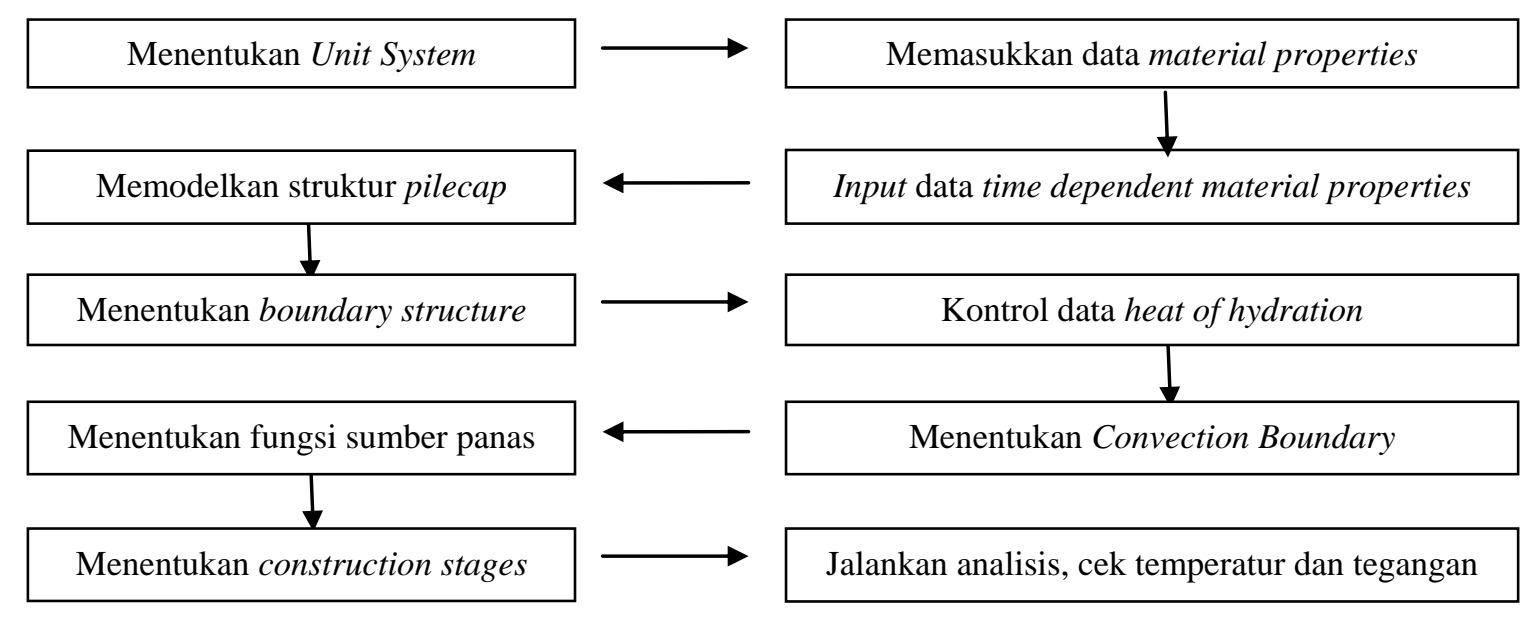

Gambar 2. Skema tahapan pekerjaan menggunakan Midas Civil 2018.

\section{Variabel bebas}

Variabel bebas yang akan dipakai pada penelitian ini adalah opsi curing dan initial temperature. Tipe semen juga akan menjadi hal utama dalam penelitian ini, yaitu dengan menggunakan semen Portland tipe I.

Untuk penggunaan semen OPC tipe I dapat diatur pada fungsi sumber panas seperti pada gambar 3 berikut ini.

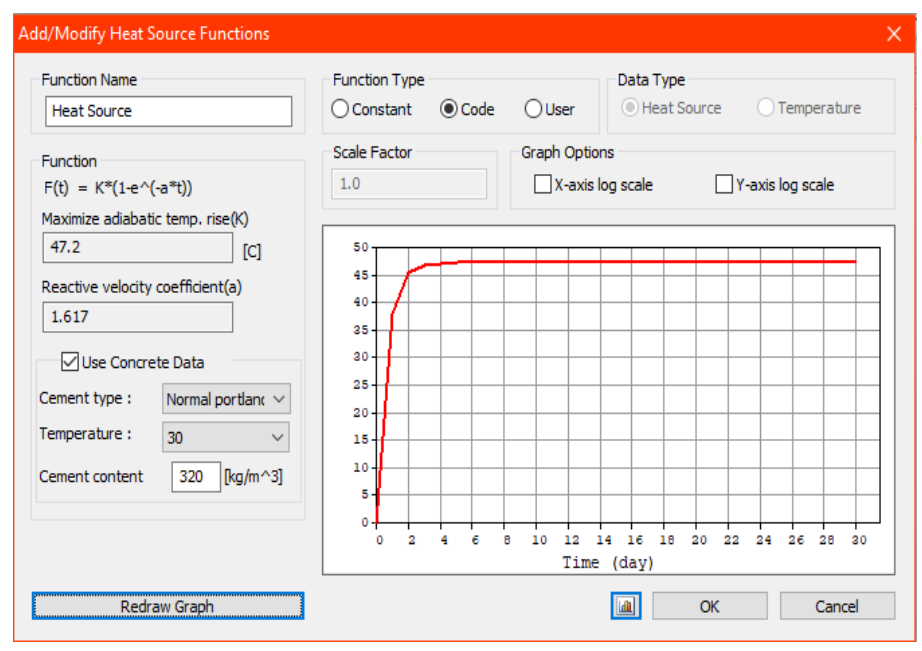

Gambar 3. Penentuan Heat Source Functions. 
Untuk initial temperature, dapat diatur pada kontrol data panas hidrasi seperti pada Gambar 4 berikut ini.

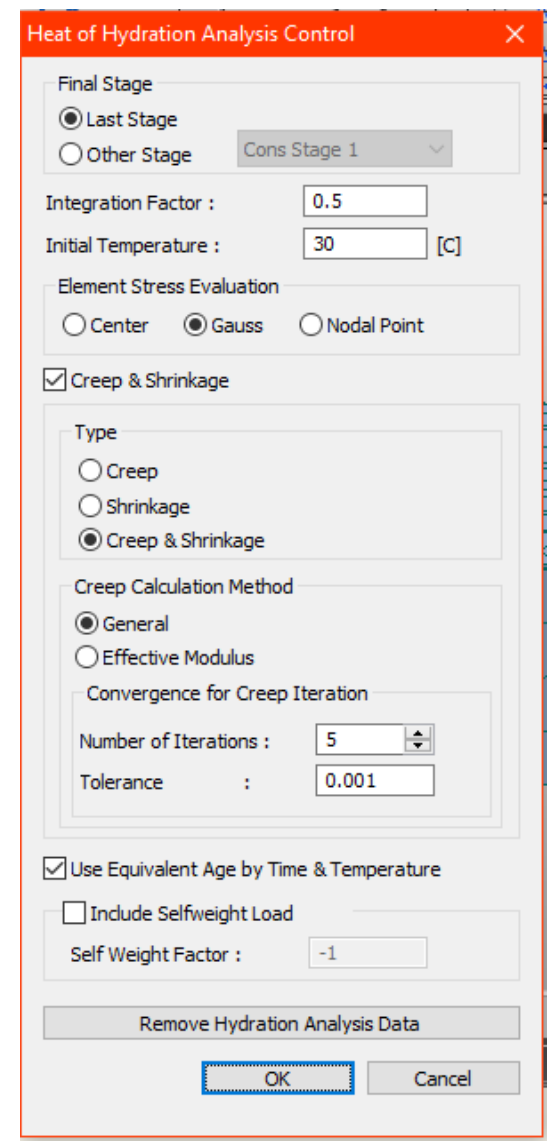

Gambar 4. Heat of Hydration Analysis Control

Untuk opsi curing dapat ditentukan pada bagian construction stages, dimana setiap waktu dapat ditentukan tahapan konstruksi secara menyeluruh, seperti ditunjukkan pada Gambar 5 berikut ini.

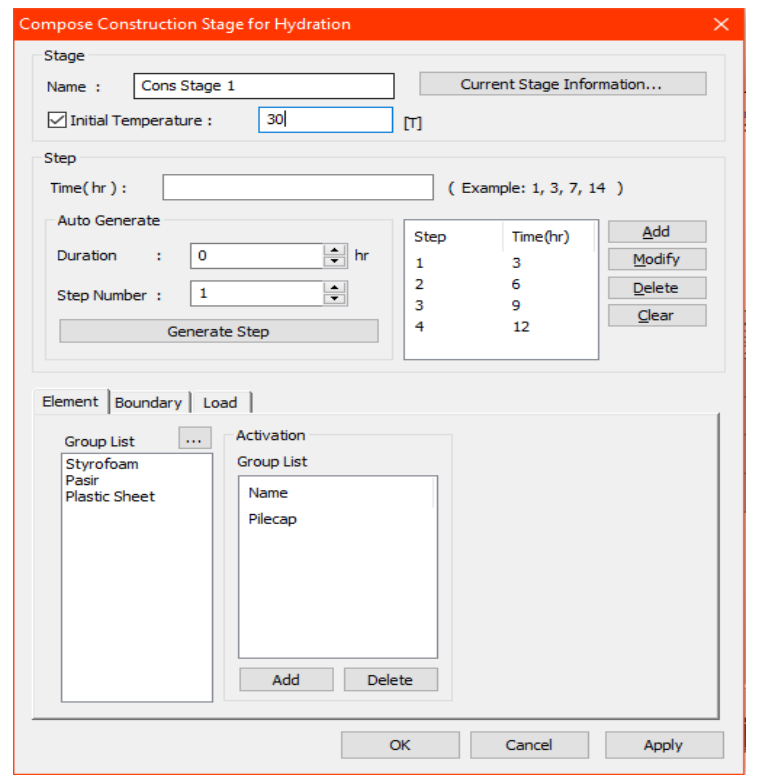

Gambar 5. Construction Stages. 


\section{HASIL ANALISIS}

Hasil yang didapat berupa temperatur dan tegangan dari beberapa kondisi.

Untuk kondisi tanpa curing dan suhu awal $\pm 18^{\circ} \mathrm{C}$ (air es) didapat perbedaan temperatur sebesar $33^{\circ} \mathrm{C}$ sesuai dengan Gambar 6.

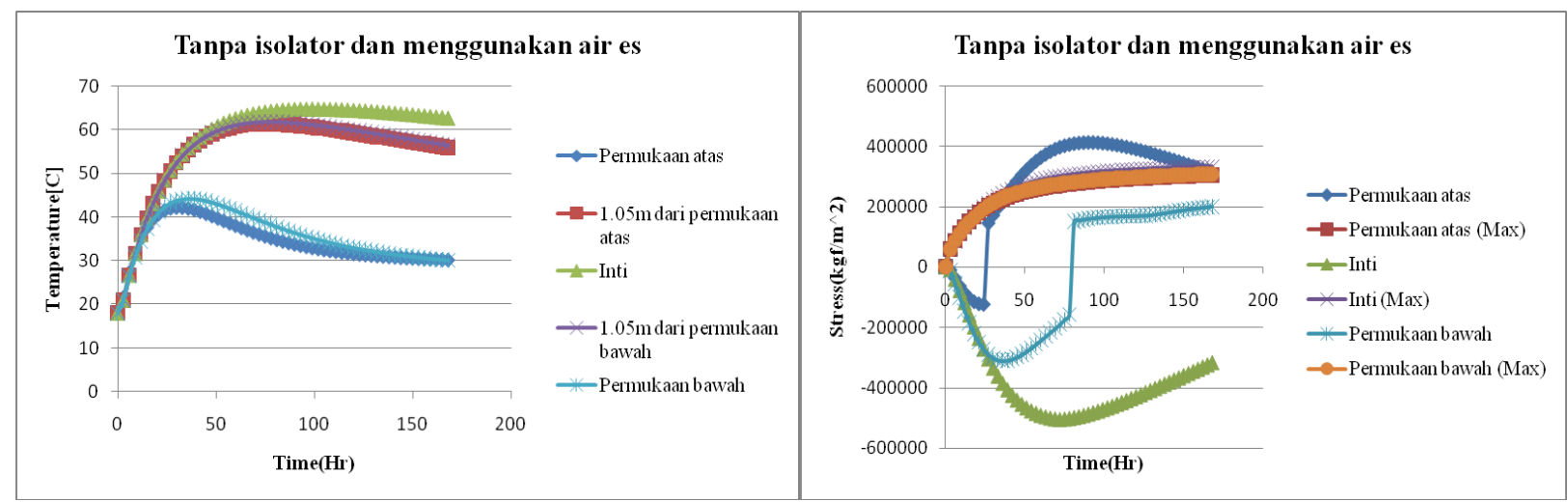

Gambar 6. Grafik temperatur dan tegangan tanpa isolator dan suhu awal $\pm 18^{\circ} \mathrm{C}$

Untuk kondisi dengan curing dan suhu awal $\pm 18^{\circ} \mathrm{C}$ (air es) didapat perbedaan temperatur sebesar $11,7^{\circ} \mathrm{C}$ sesuai dengan Gambar 7.

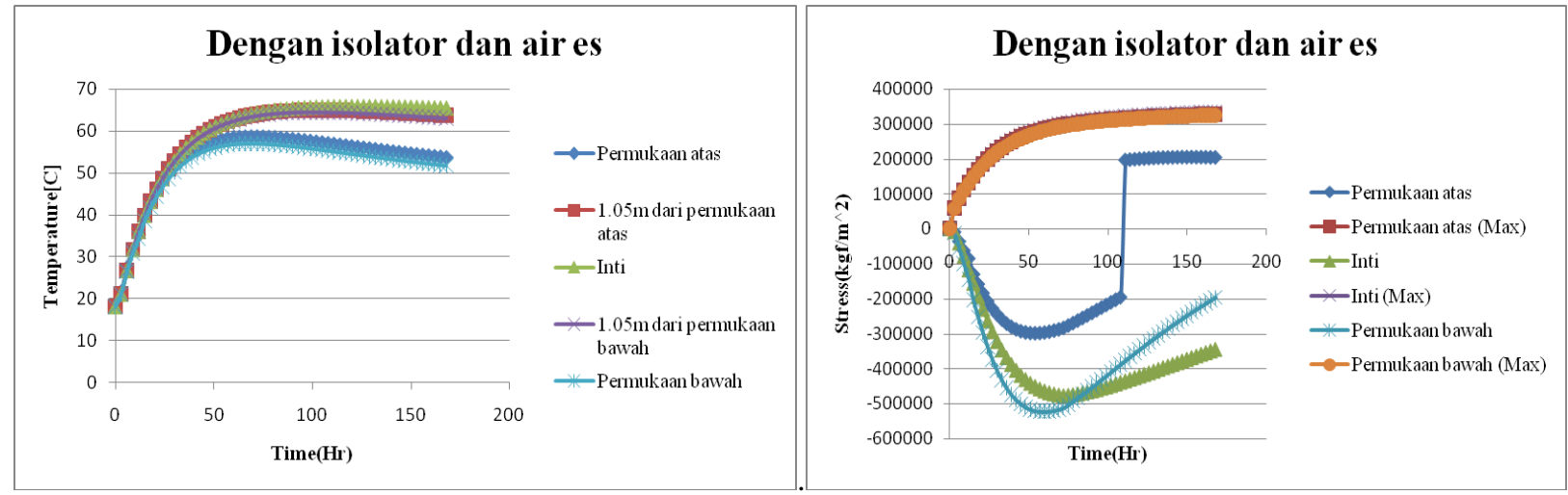

Gambar 7. Grafik temperatur dan tegangan dengan isolator dan suhu awal $\pm 18^{\circ} \mathrm{C}$

Untuk kondisi dengan curing metode buka tutup dan suhu awal $\pm 18^{\circ} \mathrm{C}$ (air es) didapat perbedaan temperatur sebesar $30,0^{\circ} \mathrm{C}$ sesuai dengan Gambar 8 .

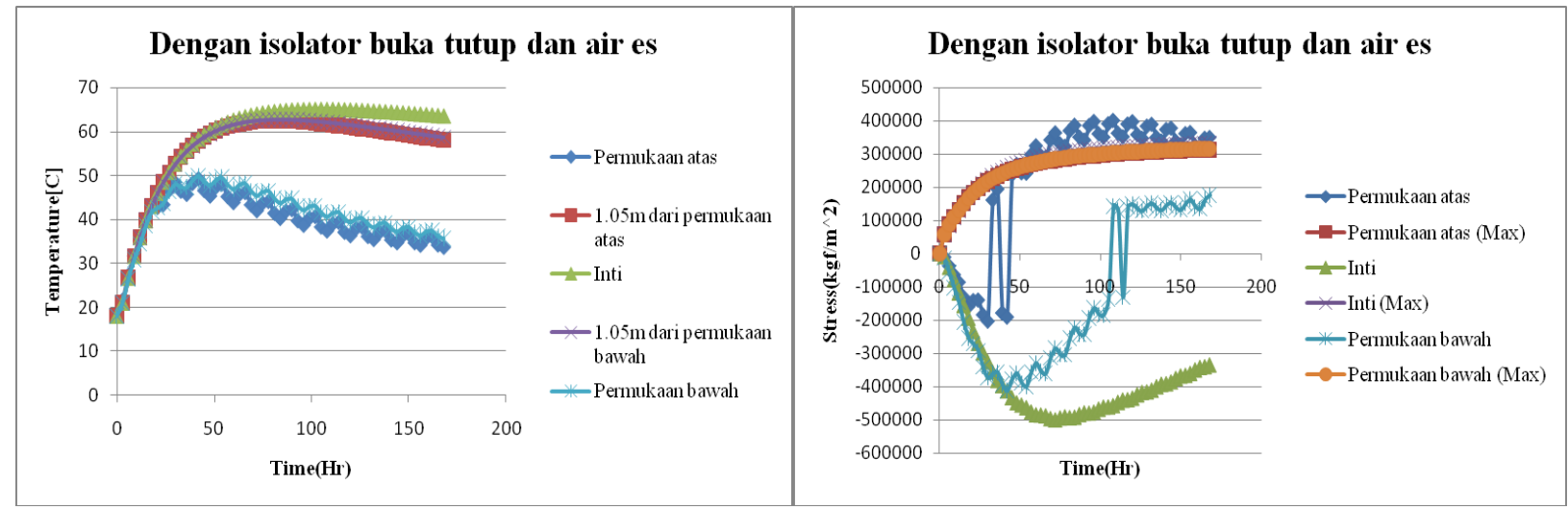

Gambar 8. Grafik temperatur dan tegangan dengan isolator metode buka tutup dan suhu awal $\pm 18^{\circ} \mathrm{C}$ 
Untuk kondisi tanpa curing dan suhu awal $\pm 30^{\circ} \mathrm{C}$ (air biasa) didapat perbedaan temperatur sebesar $42,2^{\circ} \mathrm{C}$ sesuai dengan Gambar 9.

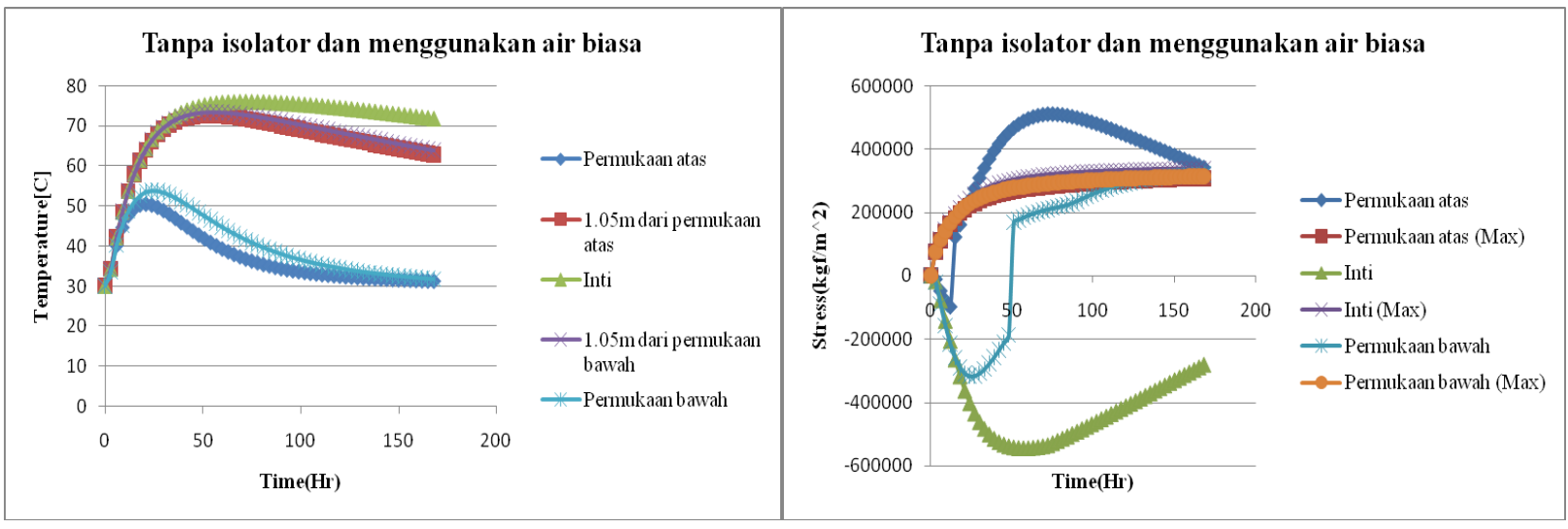

Gambar 9. Grafik temperatur dan tegangan tanpa isolator dan suhu awal $\pm 30^{\circ} \mathrm{C}$

Untuk kondisi dengan curing dan suhu awal $\pm 30^{\circ} \mathrm{C}$ (air biasa) didapat perbedaan temperatur sebesar $16,2^{\circ} \mathrm{C}$ sesuai dengan Gambar 10.

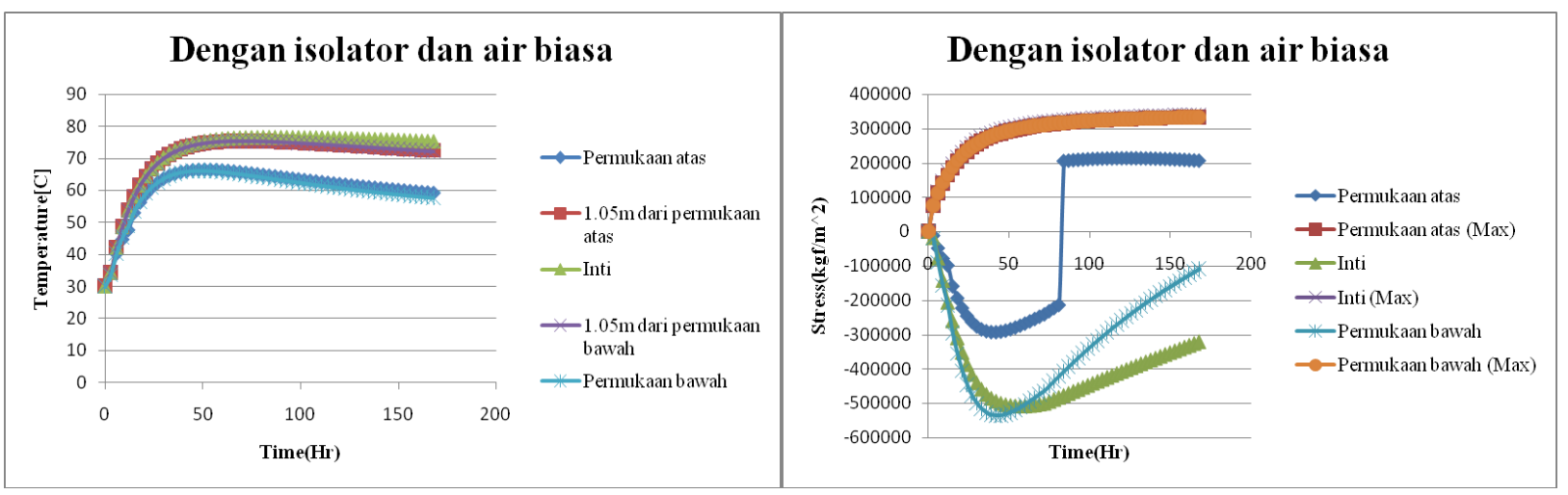

Gambar 10. Grafik temperatur dan tegangan dengan isolator dan suhu awal $\pm 30^{\circ} \mathrm{C}$

Untuk kondisi dengan curing metode buka tutup dan suhu awal $\pm 30^{\circ} \mathrm{C}$ (air biasa) didapat perbedaan temperatur sebesar $37,9^{\circ} \mathrm{C}$ sesuai dengan Gambar 11 .

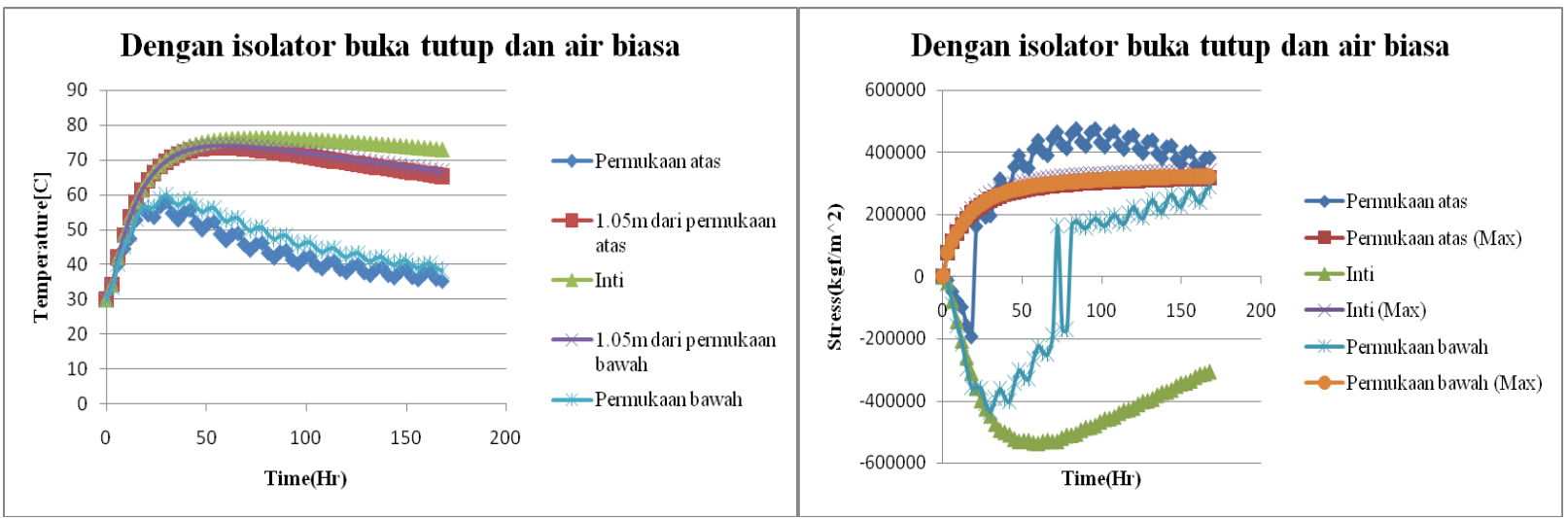

Gambar 11. Grafik temperatur dan tegangan dengan isolator metode buka tutup dan suhu awal $\pm 30^{\circ} \mathrm{C}$ 


\section{KESIMPULAN}

Berdasarkan hasil analisis heat transfer pada konstruksi pilecap Jembatan Pulau Balang, Kalimantan Timur, maka dapat ditarik kesimpulan sebagai berikut:

a. Pemakaian air es/air biasa sebagai bahan campuran adukan beton akan mempengaruhi temperatur yang dihasilkan. Sebagai contoh, pada pilecap tanpa isolator, temperatur maksimum yang dihasilkan jika memakai air es sebagai bahan campuran adukan beton sebesar $64,8^{\circ} \mathrm{C}$, sedangkan temperatur maksimum yang dihasilkan jika memakai air biasa sebagai bahan campuran adukan beton sebesar $76,1^{\circ} \mathrm{C}$.

b. Temperatur yang dihasilkan pada pilecap tanpa lapisan isolator memiliki perbedaan temperatur yang besar, yaitu $33^{\circ} \mathrm{C}$ dengan air es dan $42,2^{\circ} \mathrm{C}$ dengan air biasa. Hal ini disebabkan karena panas yang terus-menerus keluar dari permukaan beton.

c. Temperatur yang dihasilkan pada pilecap dengan lapisan isolator memiliki perbedaan temperatur yang kecil, yaitu $11,7^{\circ} \mathrm{C}$ dengan air es dan $16,2^{\circ} \mathrm{C}$ dengan air biasa. Hal ini disebabkan karena adanya peran dari lapisan isolator yang dapat menahan/mencegah panas keluar dari permukaan beton, sehingga temperatur antara permukaan dengan inti tidak terlalu berbeda jauh.

d. Temperatur yang dihasilkan pada pilecap dengan lapisan isolator buka tutup memiliki perbedaan temperatur yang cukup besar, yaitu $29,5^{\circ} \mathrm{C}$ dengan air es dan $37,5^{\circ} \mathrm{C}$ dengan air biasa. Hal ini dapat diatasi dengan membuka dan menutup lapisan isolator sedemikin rupa, karena jika tidak teratur, maka dapat berpotensi mengalami thermal shock.

e. Tegangan yang terjadi pada pilecap tanpa lapisan isolator dan pilecap dengan lapisan isolator buka tutup sudah melampaui batas tegangan yang diijinkan, hal ini disebabkan karena temperatur pada bagian permukaan dan bagian inti pilecap memiliki perbedaan yang cukup jauh $\left(>20^{\circ} \mathrm{C}\right)$. Sedangkan tegangan yang terjadi pada pilecap dengan lapisan isolator msih berada di bawah batas tegangan yang diijinkan, karena temperatur pada bagian permukaan dan bagian inti pilecap memiliki perbedaan yang kecil $\left(<20^{\circ} \mathrm{C}\right)$.

f. Cara terbaik yang dapat digunakan yaitu dengan menggunakan isolator dan temperatur awal yang rendah karena panas yang dihasilkan lebih rendah, sehingga metode ini merupakan metode curing yang tepat guna.

\section{DAFTAR PUSTAKA}

Charman, R. dan Tuson A. (2012). "Thermal Material Properties for Modelling of the 2 Metre Box".

Endawati, J. dkk. (2014). "Pengaruh Panas Hidrasi Beton Dengan Semen Tipe 2 Terhadap Ketebalan Elemen Beton".

Haebaehan, F. D. P. dan Nuryamsi. (2014). "Pengaruh Perawatan (Curing) Pada Beton Dengan Limbah Abu Boiler Pabrik Kelapa Sawit (PKS) Sebagai Substitusi Semen Terhadap Kuat Tekan Beton”.

Han, Tong-Seok. dkk. (2013). "Evaluation of Thermal Conductivity for Thermally Insulated Concretes".

Kim, Soo Geun. (2010). "Effect of Heat Generation From Cement Hydration on Mass Concrete Placement".

Neville, A. M. (2012). Properties of Concrete 5th Edition. Pearson Education Limited.

Nugraha, Paul dan Antoni. (2007). Teknologi Beton Dari Material, Pembuatan, dan Beton Kinerja Tinggi. Andi Publisher.

Nuryadin, A. K. (2012). “Analisa Panas Hidrasi Pada Pondasi Bored Pile di Laut Menggunakan Software Midas Pada Proyek Jembatan Suramadu."

Pratama, S.W.I. dkk. (2015). "Pembuatan dan Pengujian Kualitas Semen Portland Yang Diperkaya Silikat Abu Ampas Tebu".

Priambodo, I.S. (2016). "Pengaruh Penambahan Fly Ash Terhadap Kualitas Fisika dan Kimia Pada Produksi Portland Composite Cement (PCC)".

Suryawijaya, M. (2012). "Studi Pengaruh Temperatur Beton Massa Dengan Ketebalan 4 Meter".

Vijayalakshmi, M. "Concrete Technology".

Widojoko, L. (2010). 'Pengaruh Sifat Kimia Terhadap Unjuk Kerja Mortar”. Jurnal Teknik Sipil UBL1. 